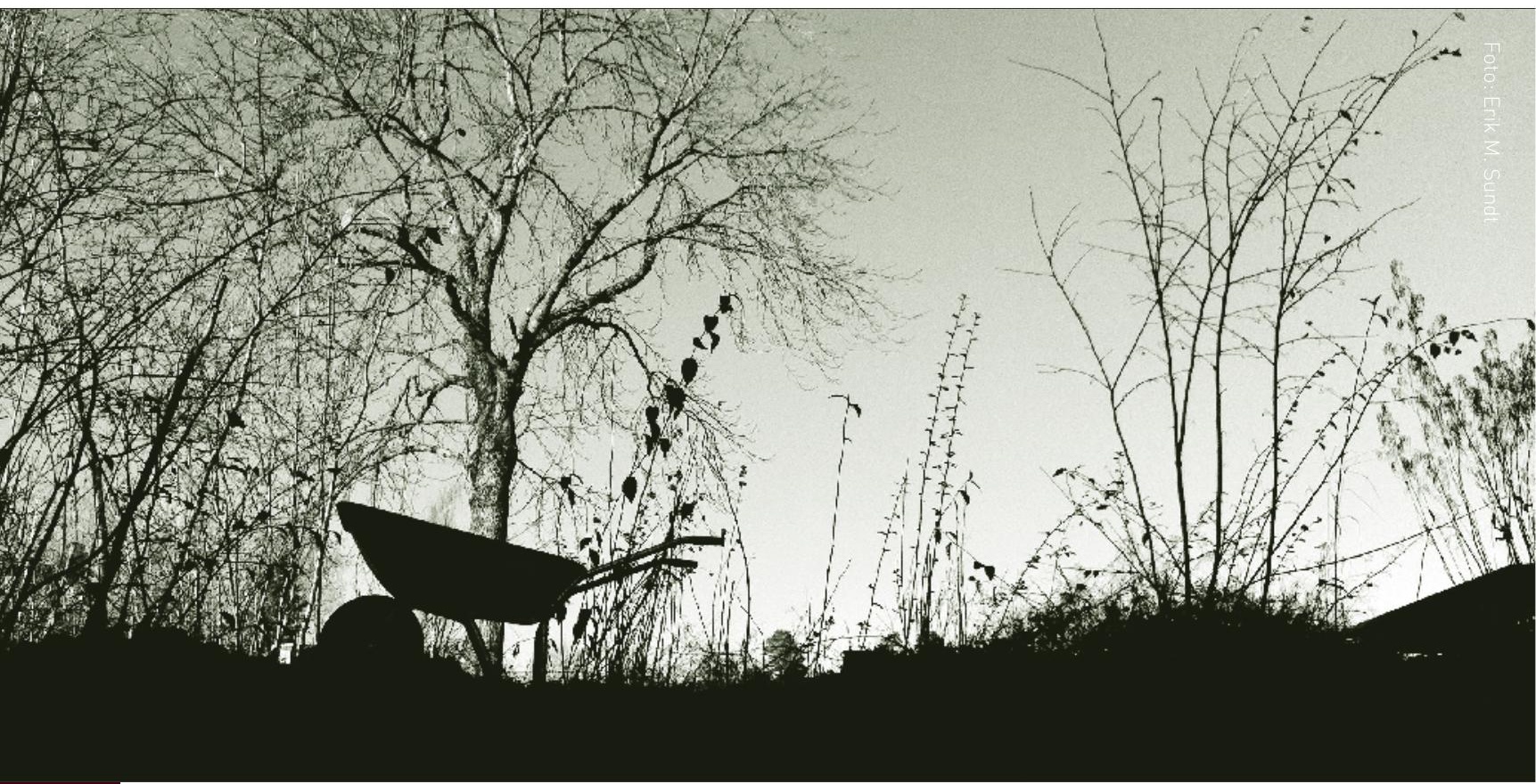

Bakgrunn: $\emptyset$ kende medisinsk og teknologisk utvikling gir store utfordringer til dagens helsepersonell. Forskning innenfor pleie og behandling øker og det stilles store krav om at denne forskningen skal komme pasientene til gode. Ny viten og økte krav til kompetanse gjør at helsepersonell må holde seg faglig oppdatert og jobbe kunnskapsbasert. Det er fortsatt store utfordringer knyttet til å implementere kunnskapsbasert praksis.

Hensikt: Hensikten med denne litteraturstudien er å undersøke hvilke

Implementing evidence-based practice in hospital - what strategies are effective?

Background: Inclining medical and technological development generates large challenges for current health professionals. Research within nursing and treatment is rising. New knowledge and rising demands forces health professionals to stay updated within the field, and use evidence-based practice. However, there are still large challenges to address in order to implement evidence-based practice.

Objective: The purpose with this strategier som er effektive når man skal implementere kunnskapsbasert praksis i sykehus.

Metode: Litteraturstudie. Søkene ble gjort i januar 2010 i følgende databaser: Cochrane Library, Cochrane Effektive Practice and Organisation og Care Group (EPOC), Medline, Pubmed og Cinahl.

Resultat: Våre funn er basert på 11 studier. Tre av studiene er systematiske oversiktsartikler fra Cochrane Library, og åtte er enkeltstudier. Vi har valgt å oppsummere disse i fire hovedområder som til dels er overlappende: Betydning av barrierer, ressurser, kompetansebygging / fagutvikling og ledelse.

Konklusjon: Intervensjoner rettet mot ledelse og organisatoriske infrastrukturer, samt tiltak mot kartlagte barrierer synes å ha en betydning for å lykkes med implementering av kunnskapsbasert praksis. Helsepersonells evne til å kunne lese og forstå forskning er viktig. De ansatte må involveres og kunne se nytten av forskningen i praksis. literature study is to find out what strategies to use when implementing evidence-based practice at a hospital.

Methods: Literature study. The search was done in January 2010 in the following databases: Cochrane Library, Cochrane Effective Practice and Organization and Care Group, (EPOC), Medline, Pubmed and Cinahl.

Results: Our article is based on 11 studies. Three of the studies are reviews from Cochrane Library, and eight are single studies. We have chosen to summarize these in four main elements: mapping of barriers, resources, proficiency development/ profession development, and management.

Conclusion: Interventions directed towards management and organised infrastructures, as well as mapping of barriers seems to be decisive factors to success when implementing evidence-based practice. The health professionals' ability to read and understand science and research is important. The employees must be involved and be able to see the usefulness of the research in practice.

Key words: evidence-based nursing, implementation, staff development / professional competence 


\section{» Hvilke strategier er effektive ved implementering av kunn- skapsbasert praksis i sykehus?}

Forfattere: Gunn K. Sandvik, Kjersti Stokke og Monica W. Nortvedt

\section{NøKKELORD}

- Kunnskapsbasert sykepleie

- Forskning

- Praksis

- Litteraturstudie

Helsetjenesten stilles overfor stadig større krav til kvalitet og forskning. Pasientene har mer kunnskap og innflytelse enn noen gang. De forventer den beste behandling og pleie, og krever at det skal være høy kvalitet på helsetjenesten. Å utøve kunnskapsbasert praksis er å ta faglige avgjørelser basert på systematisk innhentet forskningsbasert kunnskap, erfaringsbasert kunnskap og pasientens ønsker og behov $\mathrm{i}$ den gitte situasjon (1). Organisasjonene må vise fleksibilitet og det må legges til rette for implementering av den nye kunnskapen. Det er derfor aktuelt å se nærmere på forskning om implementering for å kunne velge noen effektive strategier.

Helsepersonell har varierende grad av kompetanse om kunnskapsbasert praksis (KBP). Til tross for økt fokus på KBP, er implementeringsdelen en utfordring for sykepleiere $\mathrm{i}$ de fleste institusjoner (2). Studier fra USA viser at selv om de fleste sykepleiere aksepterer forskningens betydning, er det et fåtall som anvender denne kunnskapen i praksis. Kun 15 prosent av sykepleierne konstaterer at de leser forskningslitteratur (3). A implementere kunnskapsbasert praksis kan være en krevende prosess, og mange faktorer påvirker om man lykkes eller ikke. $\AA$ implementere KBP bør gjøres ved en systematisk tilnærming og basert på eksisterende forskning om implementering (2).

Det finnes ingen allmenn implementeringsstrategi når man skal innføre kunnskapsbasert praksis i en organisasjon. Hensikten med denne litteraturstudien er å få en oversikt over hvilke strategier som kan være effektive ved implementering av kunnskapsbasert praksis i sykehus eller i sammenlignbare helseinstitusjoner.

\section{METODE}

$\mathrm{Vi}$ valgte søkeord som var relevante for vår problemstilling. Vi brukte SveMed+ til å finne de engelske MESH-termene. Littera- tursøket ble utført sammen med bibliotekar i januar 2010. Det ble foretatt kombinasjonssøk på de samme ordstillingene i Cochrane Library, Medline, Pubmed og Cinahl. Søkeordene som ble brukt var (evidence based medicine OR evidence based practice OR evidence based nursing OR evidence based) AND (research utilization OR knowledge trans-

Hva tilfører denne artikkelen?

Studien viser at implementering av kunnskapsbasert praksis i sykehus forutsetter helsepersonell som kan forstå og lese forskning samt at ledelsen er resultatorientert og positiv til tiltaket.

\section{Mer om forfatter:}

Gunn K. Sandvik er enhetsleder på sengepost ved Oslo Universitetssykehus, Klinikk for kreft og kirurgi, Avdeling for kreft.

Kjersti Stokke er kreftsykepleier og prosjektleder ved Klinikk for kreft og kirurgi, Avdeling for kreft, og mastergradsstudent ved Senter for kunnskapsbasert praksis, Høgskolen i Bergen. Monica W. Nortvedt er professor og leder ved Høgskolen i Bergen, Senter for kunnskapsbasert praksis.

Kontakt:gunn.kristin.sandvika radiumhospitalet.no 
TABELL 1: Oversikt over antall relevante og inkluderte artikler

\begin{tabular}{lllr}
\hline Database & Treff & Relevante & Inkluderte \\
Cochrane Libary & 12 & 4 & 3 \\
MedLine & 251 & 69 & 6 \\
CINAHL & 227 & 20 & 4 \\
Implementation Science & Håndsøk & 7 & 2 \\
\hline
\end{tabular}

fer OR professional practice OR practice guidelines $\mathrm{OR}$ «diffusion of innovation» OR intervention OR facilitate OR Implement*). I tillegg til disse databasesøkene, foretok vi et håndsøk i tidsskriftet: «Implementation Science». Dette tidsskriftet er aktuelt for temaer som omfatter implementering og helsetjenesteforskning.

Titler og abstrakter ble lest av første og andre forfatter. Inklusjonskriteriene var at tittel eller abstrakt kunne knyttes til implementering av kunnskapsbasert praksis og undersøkelsen måtte være gjort i sykehus eller sammenlignbare helseinstitusjoner. Artiklene måtte være publisert etter 1995, og bare studier som var formidlet på engelsk eller på et skandinavisk språk ble inkludert. Vi søkte i første rekke etter oppsummert forskning i form av systematiske oversikter. Enkeltstudier som ikke var med i de inkluderte oversiktene, ble inkludert og ikke begrenset til design. Tabell 1 gir en oversikt over antall treff og inkluderte studier.

\section{RESULTAT}

Det ble inkludert 11 studier i litteraturoversikten. Av disse var tre oversiktsartikler og åtte enkeltstudier (tabell 2). Resultatet fra disse studiene viste at ulike faktorer bidrar til å fremme helsearbeideres bruk av forskning og kunnskapsbasert praksis i klinikken. Vi har valgt å dele disse inn i fire hovedområder som til dels er overlappende: Betydning av barrierer, tilgjengelige ressurser, kompetansebygging/fagutvikling og ledelse.

\section{Betydningen av barrierer}

Oversiktsartikkelen til Cheater og Baker (4) inkluderte 15 randomiserte kontrollerte studier (RCT) gjort på helsepersonell. Forfatterne så på skreddersydde tiltak rettet mot identifiserte barrierer for endring. Studiene viste at tiltak rettet mot identifiserte barrierer kan forbedre pasientbehandlingen og pasienttilfredsheten. Kartlegging av barrierer og tiltak rettet mot disse kan være hensiktsmessig ved implementering av kunnskapsbasert praksis (4). Ut ifra de inkluderte studiene kunne man ikke vite om alle barrierer var inkludert og man kunne ikke konkludere hvilke barrierer som var de viktigste (4).

\section{Tilgjengelige ressurser}

Tre av enkeltstudiene som brukte tverrsnittsdesign fremhevet at man må rette oppmerksomheten på de ressursene man har og eventuelt mangler $(5,6,7)$. Ressursene som hadde betydning ifølge disse studiene var tid $(5,6,7)$, tilgang til datamaskiner med databaser, tidsskrifter og lærerbøker (5), hjelp fra bibliotekarer (7) og økonomiske ressurser (7). Det innebærer å anskaffe utstyr, utvikle webbaserte internettres- surser og opprette stillinger for "champions", som er eksperter $\mathrm{i}$ å fremme implementeringen av KBP. I tillegg viste resultatene til en kvalitativ studie (8) at det var av betydning for implementeringen at det ble satt av strategiske midler til gjennomføringen.

\section{Kompetansebygging}

Flere av tverrsnittsstudiene beskrev betydningen av å tilrettelegge for kompetanseheving av helsepersonell $(5,6,9,10)$. Det kreves utdanningsprogram og påfølgende muligheter for å utvikle ferdigheter til å finne, analysere og implementere forskning (6). Videre var et positivt arbeidsmiljø som er mottakelig for endring en nødvendighet for implementering av forskning i praksis. Det var også viktig at personalet hadde tro på verdien KBP har for pasientene $(6,10)$. Dette støttes også av tverrsnittstudien til Gale og Schaffer som skriver at endringen til en KBP blir lettere ved å synliggjøre fordelene for pasientene og sykepleierne (5).

Spørreundersøkelsen til Wallin et al. (7) sammenlignet to grupper sykepleiere, der den ene vedvarende arbeidet med kvalitetsforbedring og den andre ikke. Å være opptatt av fag, fagutvikling og å være med i forskningsprosjekt ble høyt rangert som fremmende faktorer for å arbeide kunnskapsbasert. Spørreundersøkelsen til Egerod og Hansen (9) konkluderte med at bruk av kliniske retningslinjer i det daglige arbeidet var en velegnet måte å veilede sykepleiere i å arbeide kunnskapsbasert på.

\section{Ledelse}

Cochranes Effective Practice and Organisation of Care groups systematiske oversikt (11) så på hvilke faktorer ved organisato- 
TABELL 2: : Matrise over inkluderte studier

\begin{tabular}{|c|c|c|c|}
\hline $\begin{array}{l}\text { Forfatter } \\
\text { (Publ.år)/ } \\
\text { Tittel/land }\end{array}$ & $\begin{array}{l}\text { Studiedesign og } \\
\text { metode }\end{array}$ & Studiestørrelse & Resultater \\
\hline $\begin{array}{l}\text { Cheater F et } \\
\text { al. (2009)/ }\end{array}$ & $\begin{array}{l}\text { Systematisk } \\
\text { oversiktsartikkel } \\
\text { Kvantitativ / } \\
\text { kvalitativ }\end{array}$ & 15 studier inkludert & $\begin{array}{l}\text { Studiene viser at tiltak rettet mot identifiserte barrierer kan } \\
\text { forbedre praksis. Det er vanskelig å si om alle barrierer er } \\
\text { kartlagt og om det er barrierer på individ eller organisa- } \\
\text { sjonsnivå som er mest fremtredende. Det påpekes likevel at } \\
\text { lokale barrierer bør kartlegges. }\end{array}$ \\
\hline
\end{tabular}

\begin{tabular}{|c|c|}
\hline $\begin{array}{l}\text { Doumit G et } \\
\text { al. (2009)/ }\end{array}$ & $\begin{array}{l}\text { Systematisk } \\
\text { oversiktsartikkel } \\
\text { RCT-studier }\end{array}$ \\
\hline
\end{tabular}

Opinionsledere kan være effektive for implementeringsprosessen.

Opinionsledere som ble identifisert av personalet hadde større påvirkning enn opinionsledere som var forutbestemt. Mer kunnskap om innflytelsen til opinionsledere etterspørres.

$\begin{array}{ll}\begin{array}{ll}\text { Foxcroft D \& } \\ \text { Cole N (2009)/ }\end{array} & \begin{array}{l}\text { Systematisk } \\ \text { oversiktsartikk } \\ \text { Retrospective } \\ \text { case study design } \\ \text { lalle 7 inkluder } \\ \text { studier) }\end{array} \\ & \\ \text { Egerod I \& } & \text { Kvantitativ/ } \\ \text { Hansen G M } & \text { Tverrsnittsde- } \\ \text { (2005)/Dan- } & \text { sign. } \\ \text { mark } & \text { Spørreskjema }\end{array}$

I utgangspunktet var det ingen studier som møtte inklusjonskriteriene. Etter at inklusjonskriteriene ble endret ble 7 studier inkludert

Spørreskjema ble sendt til 33 avdelingssykepleiere og 51 kliniske sykepleiere., fordelt på 28 avdelinger på danske sykehus $81 \%$ svar

$\begin{array}{ll}\text { French B } & \text { Kvalitativ } \\ \text { (2005)/Eng- } & \text { Observasjons- } \\ \text { land } & \text { studie }\end{array}$

Gale B V \& Kvantitativ Schaffer MA Spørreskjema (2009)/USA
3 grupper satt sammen fra ulike organisasjoner. Antall deltakere varierte fra 11-25 i hver gruppe. De hadde 3 møter over 4 mnd.

Et ikke randomisert utvalg av kliniske sykepleiere og sykepleieledere, fra 8 akuttmottak 72 kliniske sykepleiere og 20 sykepleieledere deltok

$21,5 \%$ svar: $41 \%$ av lederne og 7,5\% av kliniske sykepleiere

159 operasjonssykepleiere

$51 \%$ svar
Infrastrukturer har betydning, men det er vanskelig å si hva som er den beste intervensjonen for å implementere KBP. Det er nødvendig med mer forskning der man prøver ut ulike implementeringsstrategier.

Kliniske sykepleiere som blir kontinuerlig utdannet får $ø$ kt status.KBP basert på bruk av kunnskapsbaserte retningslinjer forbedrer den faglige kvalitet og gjør at sykepleiere arbeider forskningsbasert.

Det er viktig

- å ha kompetanse i å anvende forskning i praksis.

- å få frem verdiene, preferansene og arbeidsmetodene til interessentene.

- å identifisere organisatorisk struktur og ledelse.

- å utdanne de som skal ha spesielle roller i implementeringsfasen til en KBP.

- at sykepleiere som arbeider med å utvikle retningslinjer får støtte fra ledelsen.

Det er nødvendig å sette av tid til å lære opp sykepleiere i anvendelse av KBP.

Fordelene for pasientpleien må synliggjøres.

Det er en forutsetning å ha tilgang til databaser og tidsskrifter.

Ledere må støtte de ansatte i å arbeide kunnskapsbasert. Det er nødvendig å involvere lederne for å få til en vellykket implementering.

Ansatte bør delta i diskusjonen, planleggingen, prosjekteringen, gjennomføringen og evaluering av implementeringen.

De miljømessige barrierer viser seg å være dominerende.

De mest beskrevne barrierene:

-er at litteraturen ikke er lett tilgjengelig

-er mangel på tid

-er mangel på støtte fra legene

-er mangel på egnede lokaler

-at det er vanskelig å forstå forskningslitteratur 


\begin{tabular}{|c|c|c|}
\hline $\begin{array}{l}\text { Forfatter } \\
\text { (Publ.år)/ } \\
\text { Tittel/land }\end{array}$ & $\begin{array}{l}\text { Studi- } \\
\text { edesign og } \\
\text { metode }\end{array}$ & Studiestørrelse \\
\hline $\begin{array}{l}\text { Nagy S et } \\
\text { al.(2001)/ } \\
\text { Australia }\end{array}$ & $\begin{array}{l}\text { Kvalitativ/ } \\
\text { Kvantitativ } \\
\text { Intervju/ } \\
\text { Spørre- } \\
\text { skjema }\end{array}$ & $\begin{array}{l}12 \text { sykepleiere ble intervjuet } \\
816 \text { sykepleiere svarte på spørre- } \\
\text { skjema } \\
65 \% \text { svar }\end{array}$ \\
\hline
\end{tabular}

Novak D, Dooley S \& Clark $\mathrm{R}(2008) /$ USA Kvalitativ

Stelter C B et al.(2009) / USA

Wallin L, et al. (2003)/Sverige
Kvalitativ Individuelle intervju og fokusgruppediskusjon
Kvalitativ/ Kvantitativ-

Tverrsnittsdesign. Intervju: individuell +fokus/ Spørreskjema/ Feltstudie - observasjon/ Dokumentasjonsanalyse

Kvantitativ Spørreundersøkelse
9 personer ble intervjuet. Etter intervjuet deltok 7 av de $9 \mathrm{i}$ fokusgruppediskusjon

Alle 9 fikk anledning til å komme med tanker og ideer som oppfølging til intervju og fokusgruppe, skriftlig og anonymt.

\section{Resultater}

Det identifiseres 6 faktorer som sykepleiere anser nødvendig for utviklingen av KBP.

1. Organisasjonen, arbeidsmiljø og ledelse må være støttende til KBP

2. Sykepleiere må forstå verdien av KBP for pasientpleien

3. En KBP krever ferdigheter i lesing og vurdering av forskning

4. Det må finnes klinisk relevant forskning

5. Det kreves kjennskap til forskningsspråk og statistikk

6. Det kreves beskyttet tid til å arbeide med KBP

For å få til en KBP anbefales det å:

- bygge et miljø på postplan med tverrfaglige team som generer «Bestpraksis» initiativer - etablere Web-baserte internettressurser - ha forskningstilretteleggere (Champions) til å skape en best- praksis kultur

- utvikle en klar forståelse av nåværende praksis og grad av beredskap for endring

- ha dialog med personalet for å registere graden av engasjement og samle inn gode ideer

- vurdere i hvilken grad sykepleiere har eierforhold og tar ansvar for å oppdatere klinisk praksis, gitt de konkurrerende krav til daglig arbeid. - etablere anerkjennelse og belønningssystem for gjennomføring av kliniske kunnskapsbaserte prosjekter

- sette av strategiske midler til gjennomføring

For å få til en KBP anbefales det å:

- ha nøkkelpersoner som leder endringsarbeidet - skape et miljø som er mottagelig for KBP. - identifisere motstand i organisasjonen. - stimulere til et aktivt engasjement fra formelle og uformelle ledere på alle nivå av organisasjonen - et stimulerende miljø for nøkkelpersoner som leder endringene

- ha en stor andel av sykepleiere med høyere utdanning og sykepleiere / ledere med kompetanse innen KBP

- ha eksplisitt støtte fra toppledelsen i organisasjonen som bør ha en strategisk visjon og ikke et sporadisk og periodevis engasjement - utvikle en strategisk plan for implementeringsprosessen

Spørreundersøkelse av kliniske sykepleiere.

Svar: $34 \%+20 \%$

Spørreundersøkelse av ledere.

Svar: $56 \%+50 \%$

\section{4 sykepleiere}

For å få til en KBP anbefales det å:

- øremerke tid

- utdanne og kurse personalet i anvendelse av forskning

- ha tilgang til nødvendige databaser/tidsskrift

- få hjelp fra bibliotekar ved litteratursøk

- være med i forskningsprosjekt 
risk infrastruktur som fremmet implementering av kunnskapsbasert praksis. Organisatorisk infrastruktur kunne ifølge forfatterne være handlingsplan og verdigrunnlag, arbeidsmønster, forskning og fagutviklingsprogram, kliniske utviklingsprogram/stige med mer. Studiene fikk frem betydningen av organisatorisk infrastruktur ved implementering av KBP og viktigheten av å evaluere prosjekter nøye og bruke robuste studiedesign.

Oversiktsartikkelen til Doumit og Gattellari (12) inkluderte 12 RCT-studier. Forfatterne så på om bruk av rollemodeller (opinionsledere) hadde effekt for å bedre klinisk praksis og pasientbehandling. Fire av studiene sammenlignet bruk av rollemodeller alene mot en ikke intervensjon kontrollgruppe. I åtte av studiene sammenlignet de bruk av rollemodeller med andre intervensjoner som audit og feedback, forelesninger/ undervisning og utlevering av informasjonsmateriell. Det ble konkludert med at bruk av rollemodeller kan være effektivt for å fremme ønskelig adferd.

Den kvalitative studien til French (13) fremhevet at det ikke var nok å lære sykepleiere å håndtere informasjonen, men at de også måtte få redskaper til å implementere forskningsresultatene til egen praksis. Studien påpekte også at spesielt leger påvirker hvilke tiltak sykepleierne iverksetter i sitt praktiske arbeid. Videre hadde organisering av klinikken og ledelsesstruktur betydning. De foreslo derfor at man identifiserer organisasjonens kompleksitet og ledelsesstruktur for å legge til rette for implementering. Støtte fra ledelsen var en sentral faktor som ble presisert i flere av studi- ene $(5,6,8,10,13)$.

Den kvalitative studien til Novak, Doodley og Clark (8) konkluderte med at det å bygge en «grasroteffekt» på postplan med tverrfaglige team kan ha betydning for implementeringen. De fremhevet videre betydningen av å begynne oppbyggingen av arbeidet $\mathrm{i}$ den kliniske virksomheten med vedvarende organisatorisk støtte.

\section{DISKUSJON}

Ut ifra de inkluderte studiene i denne oversikten er det vanskelig å gi noen klare føringer. Det er få studier som har sett på effekt av tiltak for implementering av KBP. Flere av studiene er små med lite robust design. Det går likevel igjen at tiltak rettet mot lokale barrierer, kartlegging av ressurser, kompetanseheving og ritet til å endre praksis og utilstrekkelig kompetanse til å lese og vurdere forskningslitteratur.

Mangel på samarbeid med legene oppgis også som en barriere for å jobbe kunnskapsbasert. Sykepleierne støtter seg ofte til hva legene anbefaler (13). $\AA$ kunne diskutere kunnskapsgrunnlaget for våre avgjørelser i klinisk praksis vil kunne styrke sykepleieutøvelsen. Ved at sykepleierne har denne kompetansen vil sykepleiefaget bli mer synliggjort og kunnskapsbasert.

\section{Ressurser}

$\AA$ A legge til rette for og gi tid til at sykepleiere lærer seg KBP samt får mulighet til å endre praksis er av betydning $(5,6,7)$. Når man planlegger å innføre en praksis som er kunnskapsbasert, må man sørge for tilgang til data-

\section{For at sykepleiere skal kunne se nytten av forskning i praksis er det en fordel at forskningen er klinisk orientert.}

ledelse har betydning.

\section{Barrierer}

Vi kan ut fra resultatene av de inkluderte studiene si at det er av betydning å identifisere lokale barrierer og at det er viktig å sette inn tiltak på flere ulike nivå. Barrierene kan kartlegges gjennom for eksempel intervju, spørreskjema, fokusgrupper med mer.

I Norge har man gjort en kartleggingsstudie av barrierer blant operasjonssykepleiere (14). Resultatene fra denne studien samsvarer med resultater fra internasjonale studier $(4,5,6)$, som viser at viktige barrierer for bruk av forskningskunnskap kan være liten tid til implementering av ny kunnskap, mangel på auto- baser og tidsskrifter. Disse gir bakgrunnskunnskap og hjelper oss til å svare på spørsmål knyttet til endring i praksis. I tillegg må man sette av tidsressurser til gjennomføringen (5). Den økende tilgangen til internett på arbeidsplassene og den nasjonale satsningen på fri tilgang til Helsebiblioteket gir helsepersonell gode muligheter til å kunne søke etter relevant forskning, og få adgang til systematiske oversikter og artikler i fulltekst. Både i opplæringsfasen og i gjennomføringsfasen er bibliotekarer en viktig ressurs for å kunne søke etter relevante studier (7). Studiene viser også at man trenger økonomiske ressurser for å anskaffe utstyr, utvikle webbaserte internettressurser og opprette stillinger eller utvikle 
ressurspersoner i $\mathrm{KPB}(7,8)$.

\section{Kompetanse}

For å kunne implementere KBP i en organisasjon må man utdanne personalet og øke deres ferdigheter og kompetanse innenfor dette feltet. Ferdigheter i å stille fokuserte spørsmål, søke etter forskning og kritisk vurdere forskning har betydning for å kunne jobbe kunnskapsbasert. Dette øker også sykepleiernes evne til å påvirke i organisasjonen, noe som igjen er av betydning for å implementere KBP. Ferdigheter i litteratursøk handler om å kunne bygge opp en effektiv søkestrategi og finne relevant litteratur som man kan stole på $(5,6,10,13)$.

$\AA$ tilegne seg ferdigheter i kritisk vurdering av forskning enkelte pasientsituasjon. Dette kan gi de ansatte mulighet til å praktisere en kunnskapsbasert praksis, uten å ha inngående kompetanse i den kunnskapsbaserte praktiske prosessen (1). Dette kan være en god strategi på kort sikt for å fremme kunnskapsbasert praksis. På lengre sikt er det likevel viktig at kliniske sykepleiere har denne kompetansen slik at det kan foregå en kontinuerlig fagutvikling.

\section{Ledelse}

Kunnskapsbasert praksis må utvikles i samarbeid med de som styrer de organisatoriske ressursene. Sammen med behovet for bedre ferdigheter i KBP blant sykepleiere er det behov for at lederne har nødvendig

\section{Pasientene har mer kunnskap og innflytelse enn noen gang.}

er utfordrende for mange sykepleiere. Det er nødvendig med opplæring og trening. Disse studiene forteller lite om hvordan man rent praktisk skal organisere kompetansehevingen, og det er behov for mer forskning på dette feltet. Man kan diskutere om alle sykepleiere i en institusjon trenger inngående kunnskap om KBP. Det vil i tilfelle være et stort økonomisk løft. Alternativt kan man utdanne det Novak et al. og Wallin et al. kaller for "champions» eller ressurspersoner i klinikken $(7,8)$.

Sykehus bør ha retningslinjer, prosedyrer, beste praksis og anbefalinger av høy kvalitet som inkluderer forskningsresultater. Disse bør brukes av de ansatte slik at de kan ta velinformerte avgjørelser i den kompetanse og trening innen endringsledelse. Å implementere KBP handler i stor grad om endringsledelse (6). Å involvere lederne på de ulike nivåene innenfor organisasjon kan gjøre dem til viktige pådrivere for en vellykket implementering (5).

For å skape delaktighet er det viktig at sykepleierne deltar i diskusjonene, planleggingen, gjennomføringen og evalueringen av praksis (5). Ifølge studien til Nagy et al. (8) bør ledelsen demonstrere sin støtte åpenlyst og skape et miljø hvor sykepleiere blir oppmuntret til aktivt å være med i beslutningsprosesser. Gale og Scaffer differensierer hvordan støtten gis til de som er uerfarne og erfarne $i$ sykepleiefaget (5).

Novak, Doodley og Clark (8) viser til at det kan være nyttig å etablere anerkjennelse - og belønningssystemer i organisasjonen for å gjennomføre kunnskapsbaserte prosjekter. De mener også det er viktig å skape oppmerksomhet rundt eksempler på bedre pasientomsorg. Wallin et al. (7) påpeker at ledere bør skape forutsetninger og rutiner for feedback på individuelt, gruppe- og organisasjonsnivå.

Anstrengelser for å endre en organisasjon til å implementere KBP, krever et proaktivt ekte engasjement av formelle og uformelle ledere på alle nivå i organisasjonen (10).

Det kan diskuteres om resultatene fra de inkluderte studiene kan generaliseres til norske forhold. Flere av studiene er utført i USA og Australia, der helsetjenesten er bygget annerledes opp. Noen av studiene er imidlertid fra Skandinavia og resultatene er ganske sammenfallende. Det er imidlertid viktig at vi i fremtiden implementerer KBP på en systematisk måte som kan evalueres og generere ny kunnskap på området.

\section{KONKLUSJON}

Forskning på implementering viser at intervensjoner rettet mot ledelse og organisatoriske infrastrukturer, samt tiltak mot lokale barrierer synes å ha betydning for å lykkes. Funnene fremhever videre betydningen av å inneha tilstrekkelig kompetanse til å kunne lese og forstå forskning. For at sykepleiere skal kunne se nytten av forskning i praksis er det en fordel at forskningen er klinisk orientert og har betydning for pasientpleien. For å fremme bruken av kunnskapsbasert praksis vektlegges i tillegg positive og resultatorienterte ledere. 
Vi ønsker à takke styringsgruppen for implementering av kunnskapsbasert praksis ved styreleder Marie Brubeim, helsefaglig rådgiver, Oslo Universitetssykehus, Radiumbos- pitalet for à vore initiativtaker og pådriver for implementeringsprosjektet. Takk også for samarbeidet med senteret for kunnskapsbasert praksis, Høgskolen i Bergen. Til slutt en stor takk til assisterende avdelingssykepleier Sigri H. Winterbo som har tatt ansvar for drift av sengeposten slik at det har vert mulig a frigiøre tid til à skrive denne artikkelen.

\section{REFERANSE}

1. Nortvedt MW, Jamtvedt G, Graverholt B. Reinar LM. A arbeide og undervise kunnskapsbasert - en arbeidsbok for sykepleiere. Oslo: Norsk Sykepleierforbund 2007.

2. Granger BB. Organizational readiness for evidence-based practice. Journal of Nursing Administration 2008;29:91-7.

3. Wallace MC, Shorten, Russell KG. Paving the way: Stepping stones to evidence-based nursing: International journal of Nursing Practice 1997;3:14752.

4. Cheater F, Baker R, Gillies C et al. Tailored interventions to overcome identified barriers to change: effects on professional practice and health care outcomes. Cochrane Database of Systematic Reviews 2009, Issue 1

5. Gale BV, Schaffer MA. Organizational readiness for evidence-based practice.
Journal of Nursing Administration 2009:39:91-7.

6. Nagy S, Lumby J, McKinley S, Macfarlane C. Nurses' belief about the conditions that hinder or support evidence-based nursing. International Journal of Nursing Practice 2001;7:314-21

7. Wallin LA, Bostrøm M, Wikblad K, Ewald U. Substaining ability in chanching clinical practice promotes evidence-based nursing care. Journal of Advanced Nursing 2003;41:509-18.

8. Novak D, Doodley, Clark R. Best practices: understanding nurses perspectives. Journal of Nursing Administration 2008;38:448-53

9. Egerod I, Hansen GM. Evidencebased practice among Danish cardiac nurses: a national survey. Journal of Advanced Nursing 2005;51:465-73.

10. Stetler CB, Ritchie JA, RycroftMalone J, Schultz AA, Charns MP. Insti- tutionalizing evidence-based practice: an organizational case study using a model of strategic change. Implementation Science 2009:4:1-19

11. Foxcroft D, Cole N. Organisational infrastructures to promote evidence based nursing practice. Cochrane Database of Systematic Reviews 2000, Issue 3 .

12. Doumit G, Gattellari M, Grimshaw J, O’Brien MA. Local opinion leaders: effects on professional practice and heath careoutcomes. Cochrane Database of Systematic Reviews 2007, Issue 1.

13. French B. Contextual factors influencing research use in nursing. Wordviews on Evidence-Based Nursing 2005;2:172-83.

14. Hommelstad J, Ruland CM. Norwegian nurses perceived barriers and facilitators to research use. AORN Journal 2004;79:621-634 